\title{
NONLINEAR MARKET BEHAVIOR AT THE ISTANBUL STOCK EXCHANGE
}

\author{
BORSA İSTANBUL'DA DOĞRUSAL OLMAYAN PIYASA HAREKETLERİ
}

\begin{abstract}
Hakan ERKUŞ ${ }^{1}$
Ahmet UĞUR ${ }^{2}$

Abstract

Advances in Mathematical and statistical methods have increased the use of non-linear methods. Especially after the stock market crash, the non-linear work has become even more important and gained rapid rate of development. Due to the high returns of the stock market stock markets have always been an attractive investment area. On the other hand it's the unpredictable movements of the stock market makes it more risky. However, non-linear methods help to stock market players to create more revenues. In the study, Turkish capital markets, Borsa İstanbul is examined. Turkey is an attractive emerging market for fund managers. The purpose of this paper is to determine the non-linear dependence and events that lead to non-linearity by using the indexes of different sectors at the Borsa İstanbul. To this end, the Hinich portmanteau bi-correlation non-parametric test that uses the windowed testing procedure is applied.
\end{abstract}

Key Words: Non Linear Market Behavior, Borsa İstanbul, Hinich Test

$\ddot{\mathbf{O} z}$

Matematiksel ve istatistiki metodlardaki gelişmeler doğrusal olmayan metodların kullanımını artırmıştır. Özellikle borsalarda meydana gelen krizlerden sonra doğrusal olmayan metodların önemi artımş ve hızlı bir gelişme göstermiştr. Borsalar yüksek getiri nedeniyle herzaman cazip bir yatırım alanı olurken diğer yandan öngörülemeyen piyasa hareketleri nedeniyle de riskte çoğunlukla yüksek olmuştur. Bununla birlikte doğrusal omayan yöntemler borsa oyuncularının daha fazla kar elde etmeleri konusunda yardımcı olmuştur. Bu çalışmada Borsa İstanbul AŞ incelenmiştir. Türkiye fon yöneticileri açısında oldukça cazip bir gelişmekte olan piyasıdır. $\mathrm{Bu}$ çalışmanın amacı Borsa İstanbul'daki farklı sektörlerin indekslerini kullanarak doğrusal olmayan bağımlılı̆̆ ve doğrusal olmamaya neden olan olayları belirlemektir. Bu amaçla, pencereleme test prosedürünü kullanan Hinich Portmanteau Bicorrelation parametrik olmayan test kullanılmıştır.

Anahtar Kelimeler: Doğrusal Olmayan Piyasa Hareketleri, Borsa İstanbul, Hinich Testi

\footnotetext{
${ }^{1}$ Dr., İnönü Üniversitesi İIBBF, İşletme Bölümü, hakanerkus@ @otmail.com

${ }^{2}$ Dr., İnönü Üniversitesi İiBF, İşletme Bölümü
} 


\section{Introduction}

Since the stock markets give the opportunity to get high returns, they have always been one of the most popular investment tools. Along with its high returns, because of its unpredictable behaviors, investment in the stock markets is fairly risky. However, the presence of nonlinearity provides opportunities to the stock market participants to make excess profits.

The subject of non-linearity in the stock markets has become more of an issue after the stock market crash of October 19, 1987. Thereafter, the non-linear studies has gained a tremendous rate of development. The main sources of this growth are the developments in the mathematical and statistical analysis of dynamic systems. This is further supported by growing studies which conclude that the observable world is nonlinearly dynamic (Lim et.al, 2003:344).

As Antoniou et.al. (1997) explained there are several sources of non-linearity in financial time series. First of all, difficulties in carrting out arbitrage transactions may lead to non-linearity. Second, if the feedback mechanism is non-linear then the series will be non-linear. Third, market imperfection such as transaction costs may lead to non-linearities in the series. Fourth,if the announcements frequency of the series is less than the frequency of observations then it may cause non-linearities. Fifth, the presence of the nonrational investors in the market may lead to non-linearities.

In the study, Turkish capital markets, namely Istanbul Stock Exchange(ISE) is examined. Turkey is an attractive emerging market for fund managers. According to the ISE annual report of 2012, ISE ranks 7th largest stock market among emerging markets in terms of value of share trading and it is 2 th largest stock market among all markets in terms of share turnover velocity. As of the year 2012, foreign investors have a share of 65,7 percent in the freefloating shares of ISE and ISE ranks 15th among emerging markets in terms of market capitalization. ISE Bonds and Bills Market, on the other hand, ranks 7th among world markets on the basis of total value of bonds trading in 2012.

The purpose of this paper is to determine the non-linear dependence and which events that lead to non-linearity by using the indexes of different sectors in the ISE. To this end, the Hinich portmanteau bicorrelation non-parametric test (Hinich and Patterson (1995) and Hinich (1996)) that uses the windowed testing procedure is applied. The Hinich portmanteau test divides the data in frames to test for non-linearity. This is the first study that examines non-linearity in the ISE sector indexes and identifies which positive/negative national and 
international events cause this non-linearity. In this way, the study provides the investors who plan to invest ib ISE and policymakers of Turkey with information about the events/subjects that cause non-linearity in the sectors of ISE.

The remainder of this paper is organized as follows. The next section briefly summarizes the existing literature related with the topics in this paper. Section 3 introduces methodology and then describes data. Section 4 analyzes the empirical findings. Finally, conclusions are presented in Section 5.

\section{Literature Review}

While the non-linearity has become prominent since the stock market crash in 1987, there isn't so much studies that invastigate the non-lienarity behaviour of ISE. Antoniou et.al. (1997) use data from the ISE from 1988 to 1993 in order to investigate the issue of effieciency. They find that up to 1990 the stock market was inefficient and the inefficiency manifested itself through non-linear behaviour. Yildiz et.al. (2008) employ an Artificial Neural Network models to predict the direction of the Istanbul Stock Exchange National 100 Indices (ISE National-100) and their model forecast the direction of the ISE National-100 to an accuracy of 74, 51\%. Ozer and Ertokatl (2010) employ nonlinearity and chaos theories to to explore the existence or nonexistence of nonlinearity and chaotic behavior of the Istanbul Stock Exchange (ISE) all share equity indices. The results of the study based on BDS, Hinich Bispectral, Lyapunov Exponent and NEGM tests reject the efficient market hypothesis that the index series examined in the study is not random, independent and identically distributed (i.i.d). Kapusuzoglu (2011) uses the methodology which based on cross sectional volatility of stock rate of return (Christie and Huang, 1995; Chang et al. 2000) in order to study the existence of herding behavior in Istanbul stock exchange (ISE) National 100 index. He finds that increasing index return rate in rising days of markets increased cross sectional volatility significantly and concludes that herding behaviour is valid in Istanbul stock exchange (ISE) National 100 index and a nonlinear relationship exists between them. Ozkaya and Ozkaya (2012) tested for both unit root and chaos in the daily returns on Istanbul Stock Exchange (ISE 100) indices from 01/01/1990 to 07/10/2009. For this aim, some unit root test tests and Lyapunov exponent test and the algorithm based on the method by Kantz (1994) are applied. The result of the Lyapunov exponent test supports for the view that the underlying process for ISE daily returns are chaotic (that is, exhibits sensitive dependence on initial conditions). 
Although there are several studies that addresses the question whether ISE-100 index return, which is calculated by the top 100 firms' stock prices, exhibit non-linearity, there exist only one study that uses the Hinich portmanteau bicorrelation non-parametric test. Y1lanc1 (2010) investigates episodic nonlinearity in Turkish Stock Market namely Istanbul stock exchange100 (ISE) using the Hinich portmanteau test jointly with Hinich-Patterson non-overlapped window procedure over the period 2 January 1988 - 31 December 2010. He finds two periods in 1988, one period in 1989 and one period in 2000 as nonlinear. Moreover, he shows that the underlying nonlinear generation process of the ISE is not persistent; that is the nonlinear dependencies appear only infrequently and temporary. This study will contribute the literature by analyzing the ISE indexes of financial, services and industrial sectors. In addition, this study makes it possible to compare the sectors by their non-linearity behaviour.

The examples of studies that uses the Hinich portmanteau bicorrelation nonparametric test are; Hinich and Patterson (1995), Hinich (1996), Hinich and Patterson (2005), Brooks (1996), Brooks and Hinich (1998), Lim et.al. (2003), Lim and Hinich (2005), Hinich and Serletis (2006), Bonilla et.al. (2006), Romero-Meza et.al (2007) and Hiremath and Kamaiah (2011). In addition to these studies, this paper will also contribute the Hinich test literature.

\section{Methodology And Data}

\subsection{Methodology}

In order to determine the non-linearity behaviour of ISE indexes, the Hinich (1996) bicorrelation test that uses Hinich and Patterson (1995) non-overlapped windowed approach is applied. The Hinich and Patterson (1995) test procedure involves dividing the full sample period into equal-length non-overlapped windows to capture episodic dependencies. Then, Hinich (1996) bicorrelation test is applied. The test procedure employs non-overlapped data window, thus if $\mathrm{n}$ is the window length, then the $\mathrm{k}$-th window is:

$\left\{\mathrm{y}\left(\mathrm{t}_{\mathrm{k}}\right), \mathrm{y}\left(\mathrm{t}_{\mathrm{k}}+1\right), \ldots, \mathrm{y}\left(\mathrm{t}_{\mathrm{k}}+\mathrm{n}-1\right)\right\}$

The next non-overlapped window is:

$\left\{\mathrm{y}\left(\mathrm{t}_{\mathrm{k}+1}\right), \mathrm{y}\left(\mathrm{t}_{\mathrm{k}+1}+1\right), \ldots . \mathrm{y}\left(\mathrm{t}_{\mathrm{k}+1}+\mathrm{n}-1\right)\right\}$, where $\mathrm{t}_{\mathrm{k}+1}=\mathrm{t}_{\mathrm{k}}+\mathrm{n}$

The $\mathrm{C}$ statistic, which is developed for the detection of linear serial dependencies within a window, is defined as:

$C=\sum_{r=1}^{L}\left[C_{Z Z}(r)\right]^{2} \sim X^{2}(\mathrm{~L})$ 
where

C $C_{Z Z(r)=(n-r)^{\frac{1}{2}} \sum_{t=1}^{n-r} Z(t) Z(t+r)}$

The $\mathrm{Z}(\mathrm{t})$ are the standardized observations, obtained by subtracting the sample mean of the window and dividing by its standard deviation. The $\mathrm{H}$ statistic, which is developed for the detection of non-linear serial dependencies within a window, is defined as:

$H=\sum_{s=2}^{L} \sum_{r=1}^{s-1} G^{2}(r, s) \sim X^{2}(L-1)\left(\frac{L}{2}\right)$

where

$G(r, s)=(n-s)^{\frac{1}{2}} C_{Z Z}(r, s)$

In both the $\mathrm{C}$ and $\mathrm{H}$ statistics, the number of lags $\mathrm{L}$ is specified as $\mathrm{L}=\mathrm{n}^{\mathrm{b}}$ with $0<\mathrm{b}<0.5$, where $b$ is a parameter under the choice of the user. Based on the results of Monte Carlo simulations, Hinich and Patterson (1995) recommended the use of $b=0,4$.

The null hypothesis for each window is that the transformed data are realizations of a stationary pure white noise process that has zero correlation $(\mathrm{C})$ and bicorrelation $(\mathrm{H})$. Thus, under the null hypothesis, the correlation $(\mathrm{C})$ and bicorrelation $(\mathrm{H})$ are expected to be equal to zero. The alternative hypothesis is that the process in window has some non-zero correlation (second order linear) or bicorrelations (third order non-linear dependence).

\subsection{Data}

In the study, daily price data of three indexes, namely industrials, services and financials indexes, from the ISE are used. The data coverage is different for different indexes which are as follows: XUSIN-BIST Industrials from 02/01/1991 to 11/03/2014, XUMAL-BIST Financials from 02/01/1991 to 11/03/2014 and XUHIZ-BIST Services from 02/01/1997 to 11/03/2014. The data used for analysis were obtained from the Istanbul Stock Exchange (ISE). The data is transformed into continuously compounded percentage daily returns using the following formula:

$$
\mathrm{R}_{\mathrm{t}}=100 * \ln \left(\mathrm{P}_{\mathrm{t}} / \mathrm{P}_{\mathrm{t}-1}\right)
$$

where $\mathrm{P}_{\mathrm{t}}$ is the closing price of the index on day $\mathrm{t}$, and $\mathrm{P}_{\mathrm{t}-1}$ the price on the previous trading day (Lim et.al, 2003:347). 
In order to remove serial correlation in the frame, which would invalidate the null hypothesis of independence of the $\mathrm{H}$ test, we fit an autoregressive (AR) model of each frame. The portmanteau bicorrelation test is then applied to the residuals of the fitted $\operatorname{AR}(\mathrm{p})$ model. It is worth noting that the AR fitting is employed purely as a 'pre-whitening' operation and not in order to obtain a model of 'best fit'. For determining the AR lag length we use Schwarz information criterion and find $\operatorname{AR}(0)$ for services, financial and

industrial return series.

After determining the lag length, the frame length of each window should be selected. The larger the frame length, the larger the number of lags and hence the greater the power of the test, but at the 'expense' of increasing the uncertainty of the event time when the serial dependence 'episode' occurs (Wild et.al, 2008). In this article, the return data is split into a set of equal-length non-overlapped moving frames of 60 .

\section{Emprical Results}

After fitting $\mathrm{AR}(0)$ model to the return series of services, financial and industrial indexes, the portmanteau bicorrelation test is then applied to the residuals of the series. Table 1 presents the results for the bicorrelation test for services returns series.

Table 1: Results of The Hinich Bicorrelation Test For Services Index

\begin{tabular}{|c|c|c|c|}
\hline $\begin{array}{c}\text { Fitted } \\
\text { AR(p) }\end{array}$ & $\begin{array}{c}\text { Total Number of } \\
\text { Windows }\end{array}$ & $\begin{array}{c}\text { Significant } \\
\text { H Windows }\end{array}$ & $\begin{array}{c}\text { Dates of Significant H } \\
\text { Windows }\end{array}$ \\
\hline AR(0) & 71 & $4(5,6 \%)$ & $16 / 08-12 / 11 / 2002$ \\
\hline & & & $06 / 05-29 / 07 / 2010$ \\
\hline & & & $17 / 10 / 2011-12 / 01 / 2012$ \\
\hline & & & $25 / 03-18 / 06 / 2013$ \\
\hline
\end{tabular}

As seen in the Table 1, there are 71 windows and 4 of these windows are found significant, in other words the null hypothesis of zero bi-correlation is rejected by $\mathrm{H}$ statistic, therefore nonlinear dependence in these windows could not be rejected. The rejection percentage is given in the parenthesis. Regarding this rate, it is obvious that the services index return series exhibits nonlinearity in a few short episodes, but in the remaining time, the series are characterized by pure noise. 
In order to provide further insight into issue of non-linearity in services index returns, we use the approach of Lim and Hinich (2005) and Lim et al (2006). They propose that the nonlinear dependency is first detected through Hinich (1996) bicorrelation with windowed procedure and identifying major events occurred during the significant window period which exhibited non-linear dependency. Following this framework, we attempt to identify those events which probably induced non-linear dependency in those window periods which are found to be significant by Hinich (1996) test. The period of significant windows of respective indixes are given in the last column of Table 1.

In the first date interval of services return series, in Turkey, there had been political conflicts and general elections. In the second interval, a very crucial amendment of the constitution was hold on a referendum. In the third interval, there had been widely terrorist attacks along the North Iraq border of Turkey and the prime minister of Turkey had an serious health operation. In the last date interval, the Federal Reserve had announced a "tapering" of some of the FED's QE policies contingent upon continued positive economic data. Moreover, Taksim Gezi Park protests started on 28 May 2013, initially to contest the urban development plan for Istanbul's Taksim Gezi Park. The subjects of the protests had, then, broadened beyond the development of Taksim Gezi Park into wider anti-government demonstrations. The protests have also spread to other cities in Turkey.

The results for the bicorrelation test for financial returns series are shown in Table 2 below.

Table 2: Results of The Hinich Bicorrelation Test For Financial Index

\begin{tabular}{|c|c|c|c|}
\hline $\begin{array}{c}\text { Fitted } \\
\text { AR(p) }\end{array}$ & $\begin{array}{c}\text { Total Number of } \\
\text { Windows }\end{array}$ & $\begin{array}{c}\text { Significant H } \\
\text { Windows }\end{array}$ & $\begin{array}{c}\text { Dates of Significant H } \\
\text { Windows }\end{array}$ \\
\hline AR(0) & 96 & $10(10,4 \%)$ & $26 / 09-20 / 12 / 1991$ \\
\hline & & & $01 / 05-01 / 08 / 1995$ \\
\hline & & & $27 / 09-21 / 12 / 1999$ \\
\hline & & & $18 / 09-08 / 12 / 2000$ \\
\hline & & & $13 / 06-05 / 09 / 2001$ \\
\hline & & & $23 / 08-19 / 11 / 2002$ \\
\hline & & & $06 / 02-21 / 05 / 2003$ \\
\hline & & & $01 / 04-25 / 06 / 2013$ \\
\hline
\end{tabular}


According to the results given in Table 2, there are 10 significant windows in which the null hypothesis of zero bi-correlation is rejected by $\mathrm{H}$ statistic. As to the key events which cause the non-linear market behaviour can be identified as follows: In the first date interval, early general election had been hold. In the second interval, there had been extensive terrorist attacks and quite a number of Turkish soldiers were killed. In the third interval, Turkey had signed a stand-by agreement with the IMF and a new banking law was enacted. In the fourth interval, a financial crisis had arised in the banking sector. In the fifthe interval, IMF had approved the credit slice of 3,2 billion dolar and the minister responsible for the economy had announced a new economic packet. In the sixth interval, as mentioned above, there had been political conflicts and general elections in Turkey. This date interval is common for services and financial sector. In the seventh interval, Turkey Parliament had rejected the crossboundary memorial for Iraq War. In the eighth interval, Turkey had signed a stand-by agreement with IMF. In the nineth interval, the civil war in Syria had affected the South border of Turkey. In the last interval which is same as the services sector, FED's tapering announcement and Taksim Gezi park protests are important events.

Table 3 gives the results for the bicorrelation test for industrial returns series. As seen in the table, there 8 significant windows, nonlinear dependence in which could not be rejected.

Table 3: Results of The Hinich Bicorrelation Test For Industrial Index

\begin{tabular}{|c|c|c|c|}
\hline $\begin{array}{c}\text { Fitted } \\
\text { AR(p) }\end{array}$ & $\begin{array}{c}\text { Total Number of } \\
\text { Windows }\end{array}$ & $\begin{array}{c}\text { Significant H } \\
\text { Windows }\end{array}$ & $\begin{array}{c}\text { Dates of } \\
\text { Significant H } \\
\text { Windows }\end{array}$ \\
\hline $\mathrm{AR}(0)$ & 96 & $8(8,3 \%)$ & $27 / 03-02 / 07 / 1991$ \\
\hline & & & $10 / 01-07 / 04 / 1997$ \\
\hline & & & $22 / 03-22 / 06 / 1999$ \\
\hline & & & $18 / 09-08 / 12 / 2000$ \\
\hline & & & $04 / 01-28 / 03 / 2007$ \\
\hline & & & $13 / 05-05 / 08 / 2010$ \\
\hline & & & $07 / 02-29 / 04 / 2011$ \\
\hline & & & $01 / 04-25 / 06 / 2013$ \\
\hline
\end{tabular}


The key events in the dates of significant Windows for industrial return series as follows: In the first interval, the head of the government party had changed. In the second interval, there had been a postmodern military coup. In the third interval, the general and local elections had been hold. The fourth interval is the same as the financial sector. In the fifth interval, the economic troubles in China had affected Turkish exchange rates and stock exchanges. The sixth date interval is same as the services sector. In the seventh interval, The European Commission had approved the fund for European aid to the most deprived members. The last date interval is common for all sectors.

\section{Conclusion}

This paper attempts to test nonlinear dependence in stock returns of three indixes at Istanbul Stock Exchange (ISE). Although the issue of nonlinear dependence has gained importance recently, it hasn't discussed sufficiently at ISE, yet. Therefore, this paper contributes to the literature of nonlinearity in ISE.

According to the results of the Hinich Bicorrelation test, the financial sector has the most nonlinear dependency, which is followed by the industrial and services sectors, respectively. However, the results also show that the nonlinear serial dependencies are episodic in nature, that is, the reported nonlinear dependencies are not consistent during the whole period. The return series of indexes follow pure noise process most of the periods. In the study, in addition to finding the episodes of presence of nonlinearity, the key events which cause this nonlinearity are also explained briefly. The major events are terrorist attacks and clashes, political conflicts and elections, IMF stand-by agreements, financial and economic crisis in the world and Turkey, Taksim Gezi Park protests and FED's tapering. Among these events Taksim Gezi Park protests and FED’s tapering have affected all three secor indexes.

Finally, it is noticeable that the financial index has the high number of significant windows, which could be explained its sensetive to the national and international economic and politic events. Therefore, it could be said that the most risky investment is the investment in financial sector, which is followed by the industrial sector and the investment in services sector has the lowest risk in Turkey.

\section{References}

Antoniou, A., N. Ergul and P. Holmes (1997) "Market Efficiency, Thin Trading and NonLinear Behaviour: Evidence from an Emerging Market", European Financial Management 3(2): 175-90. 
Bonilla C. A., M.J. Hinich and R.R. Meza (2006) "Episodic Nonlinearity in Latin American Stock Market Indices”, Applied Economic Letters, 13, pp.195-199.

Brooks, C. (1996) "Testing For Non-Linearity in Daily Sterling Exchanges Rates", Applied Financial Economics, 6, pp.307 - 317.

Brooks, C. and M.J. Hinich (1998) "Episodic Nonstationarity in Exchange Rates", Applied Economics Letters, 5(11), pp.719-22.

empirical examination on Istanbul Stock Exchange (ISE) Market", African Journal of Business Management Vol. 4(6), pp. 1140-1148.

Hinich, M. J. and D.M. Patterson (1995) Detecting Epochs of Transient Dependence in White Noise. Mimeo: Univeristy of Texas.

Hinich, M. J. and S. Apostolos (2006) "Randomly Modulated Periodic Signals in Alberta's Electricity Market," Studies in Nonlinear Dynamics \& Econometrics, De Gruyter, vol. 10(3), pages 1-15.

Hinich, M.J. (1996) “Testing for Dependence in The Input to A Linear Time Series Model”, Journal of Nonparametric Statistics 6:205-21.

Hinich, M.J., and D.M. Patterson (2005) "Detecting Epochs of Transient Dependence in White Noise", in Money, Measurement and Computation, (Eds.) Belongia, M., and Binner, J., Palgrave Macmillian, pp. 61-75.

Hiremath, G. S. and B. Kamaiah (2011) "Testing Long Memory in Stock Returns of Emerging Markets: Some Further Evidence," MPRA Paper 48517, University Library of Munich, Germany.

Istanbul stock Exchange Annual Report, 2012, http://www.borsaistanbul.com/

Kapusuzoglu, A. (2011) "Herding in The Istanbul Stock Exchange (ISE): A Case of Behavioral Finance", African Journal of Business Management Vol.5 (27), pp. $11210-11218$.

Lim, K.P. and M.J. Hinich (2005) "Cross-Temporal Universality of Non-Linear Dependencies in Asian Stock Markets”, Economics Bulletin, 7(1), pp. 1-6.

Lim, K.P., and M.J. Hinich (2005) "Cross-Temporal Universality of Non-Linear Dependencies in Asian Stock Markets", Economics Bulletin 7(1), pp. 1-6.

Lim, K.-P., M. J. Hinich. and V. K. Liew (2003) "GARCH Diagnosis with Portmanteau Bicorrelation Test: An Application on the Malaysia's Stock Market", EconWPA, http://128.118.178.162/eps/fin/papers/0307/0307013.pdf

Lim, K.P., M.J. Hinich and R.D. Brooks (2006) "Events That Shook The Market: An Insight From Nonlinear Serial Dependences in Intraday Returns", Working paper. http://papers.ssrn.com/sol3/papers.cfm?abstract_id=912603

Ozkaya, A. and R. Ozkaya (2012) "Uncovering The Chaotic Behavior of ISE 100 Stockmarket Index", African Journal of Business Management Vol. 6 (7), pp. 27272737.

Özer, G. and C. Ertokatli (2010) "Chaotic processes of common stock index returns: An

Romero-Meza, R., C. Bonilla and M.J. Hinich (2007) "Nonlinear Event Detection in the Chilean Stock Market", Applied Economics Letters 14(13), pp. 987-91. 
Wild, P., M.J. Hinich and J. Foster (2008) “Are Daily and Weekly Load and Spot Price Dynamics in Australia's National Electricity Market Governed by Episodic Nonlinearity?", School of Economics Discussion Paper No. 368.

Yıldız, B., A. Yalama and M. Coşkun, "Forecasting the Istanbul Stock Exchange National 100 Index Using An Artificial Neural Network", World Congress On Science, Engineering and Technology (December 17-19, 2008), Bangkok, Vol:36, 36-39, Waset,2008.

Yilanci, V. (2012) "Detection of Nonlinear Events in Turkish Stock Market", Journal of Applied Economic Sciences, 7(1), pp. 93-96. 